\title{
Synthesis, Preliminary Pharmacological and Acute Toxicity Studies of a New Series of 7-(2-(Benzo[d] thiazol-2-ylamino)ethoxy)-4-methyl-2H-chromen-2-one Derivatives with Atypical Antipsychotic Activity
}

\author{
A. A. GAWAI* S. DAS ${ }^{1}$ AND M. NEMADE ${ }^{2}$ \\ Department of Pharmaceutical Chemistry, Anuradha College of Pharmacy, Chikhli-443 201, ${ }^{1}$ Department of Pharmacology, \\ Assam University, Silchar-788 011, '2Department of Pharmacology, TVES's College of Pharmacy, Faizpur-425 503, India
}

Gawai et al.: Synthesis, Pharmacological Screening and Acute Toxicity of Chromen-2-one Derivatives

\begin{abstract}
The present study focused on the synthesis, preliminary pharmacological screening and acute toxicity testing of novel series of 7-(2-(benzo[d] thiazol-2-ylamino)ethoxy)-4-methyl-2H-chromen-2-one derivatives (4a-4k). This novel series was designated and synthesized by refluxing 2 -amino benzothiazoles substituted derivatives (3a-3k) with 7-(2-chloroethoxy)-4-methyl-2H-chromen-2-one (2) in dry pyridine. All the synthesized compounds were screened and evaluated for dopamine $\mathrm{D}_{2}$ and serotonin $5 \mathrm{HT}_{2}$ antagonistic activity as a measure of atypical antipsychotic property. Compounds $4 \mathrm{~b}, 4 \mathrm{c}, 4 \mathrm{e}, 4 \mathrm{~g}$ and $4 \mathrm{i}$ have shown good preliminary pharmacological activity and these compounds were subjected to acute toxicity (lethal dose) studies for determining effective dose range using probit log scale method. The therapeutic index of the selected compounds was determined to compare with other series of compounds to select better active compound(s). The structures of all compounds were confirmed using spectral studies. All the synthesized compounds showed good dopamine $\mathrm{D}_{2}$ and serotonin $5 \mathrm{HT}_{2 \mathrm{~A}}$ receptor antagonist activity, which could indicate atypical antipsychotic activity. Compounds (4e) and (4b) with electron withdrawing substituents showed better atypical antipsychotic activity.
\end{abstract}

Key words: Antipsychotic, schizophrenia, acute toxicity, effective dose, chromen-2-one

Schizophrenia is a complex disorder whose etiology and pathogenesis is not completely understood. Schizophrenia is associated with increased activity at dopaminergic and serotoninergic receptor $\operatorname{sites}^{[1,2]}$. Dopamine $\mathrm{D}_{2}$ occupancy is most important and required for an antipsychotic response. However, it has been proven that, extrapyramidal side effects are also increased with the increase of dopamine receptor occupancy above $80 \%{ }^{[3]}$. Some antipsychotic drugs like clozapine, olanzapine (fig. 1) have lower dopamine $\mathrm{D}_{2}$ occupancy with faster dissociation from the receptor ${ }^{[4-6]}$. The newer atypical antipsychotics compounds have interaction with multiple receptor targets. These drugs act through blockade of several receptors like dopamine, serotonin (5HT), adrenergic, muscarinic and histamine receptors ${ }^{[7,8]}$. In the atypical antipsychotic activity, $5 \mathrm{HT}$ receptor acts as an important target ${ }^{[9]}$. The atypical antipsychotic agents possess $5 \mathrm{HT}_{2 \mathrm{~A}}$ antagonistic activity along with $\mathrm{D}_{2}$ receptor antagonistic activity and these targets are the basis for

*Address for correspondence E-mail: drashishgawai@gmail.com

March-April 2019 the design of newer potential atypical antipsychotic agents. These potential atypical antipsychotic agents have fewer side effects ${ }^{[10-12]}$. These new potential antipsychotics will provide knowledge about the molecular mechanisms of action and is important for understanding of the pathophysiology of schizophrenia and for design of new drugs with improved efficacy and fewer side effects than the existing ones.

The aim of present work was to synthesize new molecule like chromen-2-one derivatives, which might act on $\mathrm{D}_{2}$ receptors as well as $5 \mathrm{HT}$ receptor and evaluate their pharmacological action for atypical antipsychotic activity.

This is an open access article distributed under the terms of the Creative Commons Attribution-NonCommercial-ShareAlike 3.0 License, which allows others to remix, tweak, and build upon the work non-commercially, as long as the author is credited and the new creations are licensed under the identical terms

Accepted 24 January 2019

Revised 13 June 2018

Received 12 April 2017

Indian J Pharm Sci 2019;81(2):241-248 


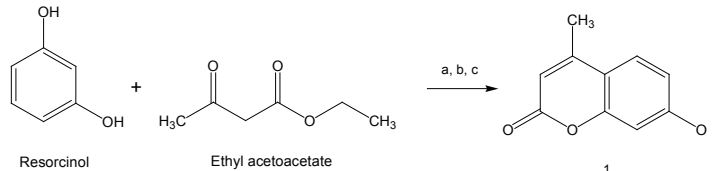

Fig. 1: Synthesis of 7-hydroxy-4 methyl-2H-chromen-2-one (1) a. Concentrated $\mathrm{H}_{2} \mathrm{SO}_{4}$, b. $5 \% \mathrm{NaOH}$, c. $2 \mathrm{M} \mathrm{H}_{2} \mathrm{SO}_{4}$

Derivatives of benzothiazole attached with chromen2-one moiety by ethoxy polar side chain linkage were synthesized. Benzothiazole derivatives were reported to have 5HT antagonistic property where as chromen2-one moiety was reported to have $\mathrm{D}_{2}$ antagonistic activity ${ }^{[13,14]}$. The aim of the present work was to synthesize some novel chromen-2-one derivatives with minimum side effects and with increased pharmacological activity. The combination of these two antagonistic moieties could possibly lead to a new series of antipsychotic drugs with reduced central nervous system side-effects.

\section{MATERIALS AND METHODS}

Melting points were determined by open capillary method on Campbell electronic apparatus and are uncorrected. All the chemicals used for the reaction were of AR grade (Sigma-Aldrich; Qualigen). All the reaction were routinely monitored and purity of the synthesized compounds was checked by thin layer chromatography by using Merck precoated silica $\mathrm{G}_{254}$ plates and visualized in iodine and UV light. The infra-red spectra were recorded by a Jasco-V-5300 Fourier-transform infrared spectroscopy (FTIR) using potassium bromide $\left(\mathrm{KBr}\right.$, transmittance, $\mathrm{v}_{\max }$ in $\mathrm{cm}^{-1}$ ) disc method. ${ }^{1} \mathrm{H}$ nuclear magnetic resonance (NMR) spectra was recorded in dimethyl sulfoxide (DMSO)- $\mathrm{d}_{6}$ on $300 \mathrm{MHz}$ Jeol spectrophotometer using tetramethylsilane (TMS) as internal reference standard (chemical shifts in $\delta, \mathrm{ppm}$ ). In this study, the synthesis of the targeted compounds was carried out as a part of Ph. D. research work at Department of Pharmaceutical Sciences, Dibrugarh University, Dibrugarh-786004, Assam, India and Pharmacological study was carried out at TVES's College of Pharmacy, Nehru Vidyanagar, Faizpur-425503, Jalgaon, Maharashtra, India.

\section{Synthesis of 7-hydroxy-4 methyl-2H-chromen-2- one (1):}

Compound (1) was prepared according to the method described by Pechmann and Duisberg ${ }^{[15]}$. One hundred millilitres of concentrated sulphuric acid (sp.gr. 1.84) was kept in an ice-bath. When temperature fell below $10^{\circ}$, a solution of resorcinol $(10 \mathrm{~g}, 0.091 \mathrm{~mol})$ and ethylacetoacetate $(13 \mathrm{ml}, 0.103 \mathrm{~mol})$ was added with continuous stirring for $2 \mathrm{~h}$. The temperature was maintained below $10^{\circ}$ throughout the addition. The reaction mixture was kept at room temperature for $18 \mathrm{~h}$ after which it was poured with vigorous stirring into a mixture of $200 \mathrm{~g}$ of crushed ice and $300 \mathrm{ml}$ of distilled water. Precipitate was collected by vacuum filtration and washed with cold water $(325 \mathrm{ml})$. The solid was dissolved in $150 \mathrm{ml}$ of $5 \%$ sodium hydroxide, filtered, and $2 \mathrm{M}$ sulphuric acid $(55 \mathrm{ml})$ was added to it with vigorous stirring until the solution was acidic. The crude product was collected by filtration at the pump, washed with cold water and dried. The product was recrystallized from ethanol to give 7-hydroxy4 methyl-2H-chromen-2-one (1) ${ }^{[15]}$. The schematic representation of the synthesis is shown in fig. 1 .

\section{Synthesis of 7-(2-chloroethoxy)-4-methyl-2H- chromen-2-one (2):}

The compound 7-hydroxy-4-methyl-2H-chromen-2one (1) $(0.01 \mathrm{~mol})$ was dissolved in $10 \mathrm{ml}$ of acetonitrile with anhydrous $\mathrm{K}_{2} \mathrm{CO}_{3}(0.01 \mathrm{~mol})$ was added to the solution. 1-Bromo-2-chloroethane, $0.01 \mathrm{~mol}$ was added drop-wise to the mixture in the round bottom flask over a period of $15 \mathrm{~min}$. The reaction was refluxed for $18 \mathrm{~h}$. The filtrate was removed under vacuum using molecular distiller to afford dry solid. The solid obtained was dissolved in dichloromethane; the organic layer was washed with water and dried over anhydrous sodium sulphate. The organic layer was separated and evaporated to dryness to afford crude product, which was then recrystallized using ethanol to get 7-(2-chloroethoxy)-4-methyl-2H-chromen-2-one (2). The schematic representation of the synthesis was shown in fig. 2.

\section{Synthesis of 2-amino benzothiazoles substituted derivatives (3a-3k):}

To $20 \mathrm{ml}$ of glacial acetic acid precooled to $5^{\circ}, 8 \mathrm{~g}$ $(0.08 \mathrm{~mol})$ of potassium thiocyanate and $1.45 \mathrm{~g}$ (0.01 mol) of substituted aniline were added. The mixture was placed in a freezing mixture of ice and salt and mechanically stirred while $1.6 \mathrm{ml}$ of bromine in $6 \mathrm{ml}$ of glacial acetic acid was added from a dropping funnel at such a rate that the temperature doesn't rise beyond $0^{\circ}$. After addition of bromine for $105 \mathrm{~min}$, the solution was stirred for an additional $2 \mathrm{~h}$ at $0^{\circ}$ and at room temperature for $10 \mathrm{~h}$. It was then allowed to stand overnight during which period an orange precipitate was settled at the bottom to which $6 \mathrm{ml}$ of water 
was added quickly and the slurry formed was heated at $85^{\circ}$ on a steam bath and filtered in hot condition. The orange residue was placed in a reaction flask and treated with $10 \mathrm{ml}$ of glacial acetic acid, heated again to $85^{\circ}$ and filtered in hot state. The combined filtrate was cooled and neutralized with concentrated ammonia to $\mathrm{pH} 6$ when a dark yellow precipitate was collected and recrystallized from benzene to get 2-amino substituted benzothiazole derivatives (3a-3k). The physicochemical characterization of these contents are shown in Table 1. The schematic representation of the synthesis is shown in fig. 3 .

\section{Synthesis of 7-(2-(benzo[d] thiazol-2-ylamino) ethoxy)-4-methyl-2H-chromen-2-one derivatives (4a-4k):}

A mixture of 7-(2-chloroethoxy)-4-methyl-2Hchromen-2-one (2) with compounds $3 \mathrm{a}-3 \mathrm{k} 0.01 \mathrm{~mol}$ was added to the reaction flask and refluxed in dry pyridine for $24 \mathrm{~h}$. The solvent was distilled off. The mixture was collected and poured on to crushed ice. The solid product was filtered and recrystallized from ethanol to obtain the final compounds (4a-4k). Physiochemical characterization of these contents are

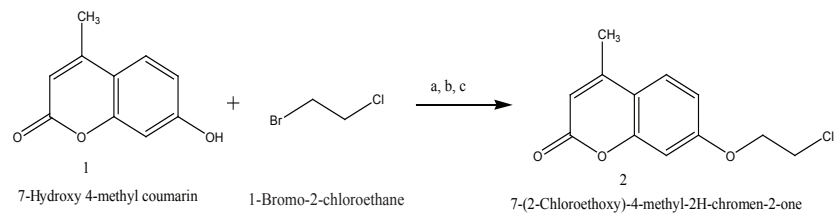

Fig. 2: Synthesis of 7-(2-chloroethoxy)-4-methyl-2H-chormen2-one (2)

a. Acetonitrile, b. anhydrous $\mathrm{K}_{2} \mathrm{CO}_{3}$, c. dichloromethane shown in the Table 2. The schematic representation of the synthesis is shown in fig. 4 .

\section{Pharmacological evaluation of atypical antipsychotic activity:}

The pharmacological evaluation of all synthesized compounds was done for atypical antipsychotic activity using apomorphine-induced climbing behaviour and 5-hydroxytryptophan (5HTP)-induced head twitches for $\mathrm{D}_{2}$ receptor and 5HT receptor inhibitory action, respectively. After preliminary pharmacological screening of atypical antipsychotic activity, some active compounds were selected for acute toxicity $\left(\mathrm{LD}_{50}\right)$ studies in female Wistar rats. $\mathrm{LD}_{50}$ was studied using Organisation for Economic Co-operation and Development (OECD) guidelines TG 425 (up and down method) and the effective dose $\left(\mathrm{ED}_{50}\right)$ was determined using probit log scale method of statistical analysis for 5HTP-induced head twitches by oral route of administration in female Wistar rats.

\section{Experimental animals:}

Albino Swiss male mice, 20-25 g, were used for preliminary screening of all synthesized compounds.

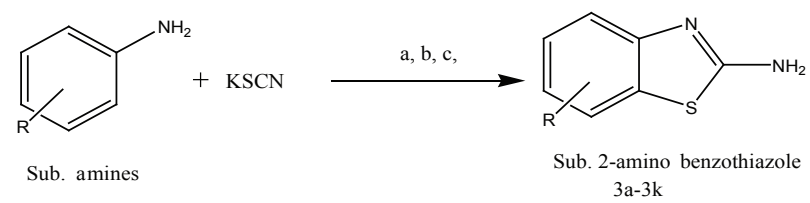

Fig. 3: Synthesis 2-aminobenzothiazole substituted derivatives (3a-3k)

a. Glacial acetic acid, b. bromine, c. benzene

TABLE 1: PHYSICOCHEMICAL DATA OF SYNTHESIZED INTERMEDIATE COMPOUNDS (3A-3K)

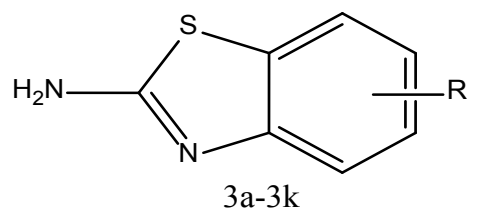

\begin{tabular}{lccccc}
\hline Compound & Molecular formula & R- Substitution & Yield (\%) & $\mathrm{mp}\left(^{\circ}\right)^{*}$ & $\mathrm{R}_{\mathrm{f}}^{*}$ \\
\hline $3 \mathrm{a}$ & $\mathrm{C}_{7} \mathrm{H}_{6} \mathrm{~N}_{2} \mathrm{~S}$ & $\mathrm{H}$ & 59 & $157-158$ & 0.65 \\
$3 \mathrm{~b}$ & $\mathrm{C}_{7} \mathrm{H}_{5} \mathrm{ClN} \mathrm{N}_{2} \mathrm{~S}$ & $6-\mathrm{Cl}$ & 57 & $169-170$ & 0.35 \\
$3 \mathrm{c}$ & $\mathrm{C}_{7} \mathrm{H}_{8} \mathrm{~N}_{2} \mathrm{OS}$ & $6-\mathrm{OCH}_{3}$ & 38 & $148-149$ & 0.58 \\
$3 \mathrm{~d}$ & $\mathrm{C}_{7} \mathrm{H}_{5} \mathrm{~N}_{3} \mathrm{O}_{2} \mathrm{~S}$ & $6-\mathrm{NO}_{2}$ & 20 & $198-199$ & 0.62 \\
$3 \mathrm{e}$ & $\mathrm{C}_{7} \mathrm{H}_{5} \mathrm{~N}_{2} \mathrm{ClS}$ & $4-\mathrm{Cl}$ & 43 & $130-131$ & 0.39 \\
$3 \mathrm{f}$ & $\mathrm{C}_{7} \mathrm{H}_{5} \mathrm{FN}_{2} \mathrm{~S}$ & $6-\mathrm{F}$ & 35 & $145-146$ & 0.58 \\
$3 \mathrm{~g}$ & $\mathrm{C}_{7} \mathrm{H}_{4} \mathrm{ClFN}_{2} \mathrm{~S}$ & $6-\mathrm{F}, 5-\mathrm{Cl}$ & 63 & $205-206$ & 0.65 \\
$3 \mathrm{~h}$ & $\mathrm{C}_{7} \mathrm{H}_{8} \mathrm{~N}_{2} \mathrm{OS}$ & $4-\mathrm{CH}_{3}$ & 48 & $183-184$ & 0.52 \\
$3 \mathrm{i}$ & $\mathrm{C}_{7} \mathrm{H}_{8} \mathrm{~N}_{2} \mathrm{~S}$ & $6-\mathrm{CH}_{3}$ & 59 & $171-172$ & 0.60 \\
$3 \mathrm{j}$ & $\mathrm{C}_{7} \mathrm{H}_{5} \mathrm{ClN}_{2} \mathrm{~S}$ & $5-\mathrm{Cl}$ & 45 & $167-168$ & 0.43 \\
$3 \mathrm{k}$ & $\mathrm{C}_{7} \mathrm{H}_{5} \mathrm{Br} \mathrm{N}_{2} \mathrm{~S}$ & $6-\mathrm{Br}$ & 36 & $138-139$ & 0.68 \\
\hline
\end{tabular}

- Melting points (mp) were uncorrected. *Mobile phase for (3a-3k) was benzene:ethyl acetate (4:1) 


\begin{tabular}{|c|c|c|c|c|c|c|c|c|}
\hline Compound & Molecular formula & $\mathbf{R}_{1}$ & $\mathbf{R}_{2}$ & $\mathbf{R}_{3}$ & $\mathbf{R}_{4}$ & Yield (\%) & $\mathrm{mp}\left({ }^{\circ}\right)^{+}$ & $\mathrm{Rf}^{*}$ \\
\hline $4 \mathrm{a}$ & $\mathrm{C}_{19} \mathrm{H}_{16} \mathrm{~N}_{2} \mathrm{O}_{3} \mathrm{~S}$ & - & - & - & - & 80 & $180-182$ & 0.6 \\
\hline $4 b$ & $\mathrm{C}_{19} \mathrm{H}_{15} \mathrm{CIN}_{2} \mathrm{O}_{3} \mathrm{~S}$ & - & - & $\mathrm{Cl}$ & - & 53 & 130 & 0.35 \\
\hline $4 c$ & $\mathrm{C}_{20} \mathrm{H}_{18} \mathrm{~N}_{2} \mathrm{O}_{4} \mathrm{~S}$ & - & - & $\mathrm{OCH}_{3}$ & - & 69 & 170 & 0.5 \\
\hline $4 d$ & $\mathrm{C}_{19} \mathrm{H}_{15} \mathrm{~N}_{3} \mathrm{O}_{5} \mathrm{~S}$ & - & - & $\mathrm{NO}_{2}^{3}$ & - & 73 & $160-161$ & 0.63 \\
\hline $4 e$ & $\mathrm{C}_{19} \mathrm{H}_{15} \mathrm{ClN}_{2} \mathrm{O}_{3} \mathrm{~S}$ & $\mathrm{Cl}$ & - & - & - & 75 & $152-153$ & 0.59 \\
\hline $4 f$ & $\mathrm{C}_{19} \mathrm{H}_{15} \mathrm{FN}_{2} \mathrm{O}_{3} \mathrm{~S}$ & - & - & $\mathrm{F}$ & - & 63 & 174 & 0.32 \\
\hline $4 g$ & $\mathrm{C}_{19} \mathrm{H}_{14} \mathrm{ClFN}_{2} \mathrm{O}_{3} \mathrm{~S}$ & - & $\mathrm{Cl}$ & $\mathrm{F}$ & - & 68 & $130-131$ & 0.38 \\
\hline $4 \mathrm{~h}$ & $\mathrm{C}_{20} \mathrm{H}_{18} \mathrm{~N}_{2} \mathrm{O}_{3} \mathrm{~S}$ & $\mathrm{CH}_{3}$ & - & - & - & 55 & $168-169$ & 0.44 \\
\hline $4 i$ & $\mathrm{C}_{20} \mathrm{H}_{18} \mathrm{~N}_{2} \mathrm{O}_{3} \mathrm{~S}$ & - & - & $\mathrm{CH}_{3}$ & - & 68 & $154-155$ & 0.60 \\
\hline $4 j$ & $\mathrm{C}_{19} \mathrm{H}_{15} \mathrm{ClN}_{2} \mathrm{O}_{3} \mathrm{~S}$ & - & $\mathrm{Cl}$ & - & - & 18 & 149 & 0.49 \\
\hline $4 \mathrm{k}$ & $\mathrm{C}_{19} \mathrm{H}_{15} \mathrm{BrN}_{2} \mathrm{O}_{3} \mathrm{~S}$ & $\mathrm{Br}$ & - & - & - & 13 & 134 & 0.55 \\
\hline
\end{tabular}

- Melting points (mp) were uncorrected. *Mobile phase for (4a-4k) was benzene:ethyl acetate (4:1)<smiles>Cc1cc(=O)oc2cc(OCCCl)ccc12</smiles>

7-(2-Chloroethoxy)-4-methyl-2H-chromen-2-one

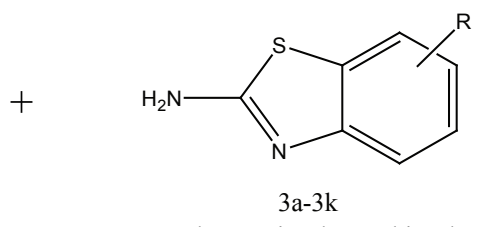

Sub. 2-amino benzothiazole

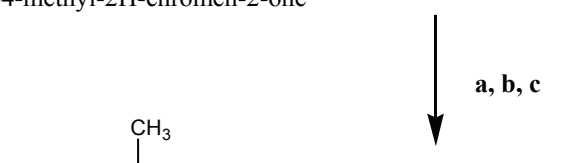<smiles>[R]c1ccc2sc(NCCOc3ccc4c(C)cc(=O)oc4c3)nc2c1</smiles>

7-(2-(benzo[d]thiazol-2-ylamino)ethoxy)-4-methyl-2H-chromen-2-one

Fig. 4: Synthesis of 7-(2-(benzo[d]thiazol-2-ylamino)ethoxy)-4-methyl-2H-chromen-2-one derivatives (4a-4k) a. Dry pyridine, b. crushed ice, c. ethanol

All compounds were suspended in $0.5 \%$ carboxy methyl cellulose (CMC) with water for injection and given by intraperitoneal (ip) route of administration. For acute toxicity and effective dose determination, healthy Wistar female rats weighing of 150-180 g were used and doses were given orally. Acute oral toxicity of selected compounds were determined by suspending the test compounds in $0.5 \% \mathrm{CMC}$ and administered by gavage at a fixed volume and studies were conducted according to the OECD guidelines TG 425. Mortality of the treated rats was recorded after $14 \mathrm{~h}$. All the animals were housed in clean plastic cages in the laboratory animal room $\left(23 \pm 2^{\circ}\right)$ on a standard pellet diet and tap water given ad libitum, with $12 \mathrm{~h}$ dark/ light cycle. Mice and rats were allowed to acclimate to laboratory conditions for at least one week before treatment.

\section{Apomorphine-induced climbing behaviour:}

The effect of test compounds on climbing behaviour was determined using apomorphine-induced climbing behaviour in mice. Animals were grouped randomly containing six animals in each group. The test groups received dose of test compounds $(5 \mathrm{mg} / \mathrm{kg})$. The control and standard group received $0.5 \% \mathrm{CMC}(5 \mathrm{ml} / \mathrm{kg})$ and olanzapine $(1 \mathrm{mg} / \mathrm{kg})$, respectively. Climbing 
behaviour was assessed in the animals by placing them individually in cylindrical wire mesh cage (height $18 \mathrm{~cm}$, diameter $14 \mathrm{~cm}) 5 \mathrm{~min}$ after administration of apomorphine $(1.0 \mathrm{mg} / \mathrm{kg})$. The animals were kept in the cage, and observed at the interval of 10,20,30 min after the administration of apomorphine. The following score was assigned to an individual animal: 0, when all four paws on the floor; 1, when two paws on the mesh; and 2, when all the four paws on the mesh. The score was summed up for each animal. Data were expressed as percentage of blockage of climbing relative to apomorphine-treated control mice ${ }^{[16,17]}$. The results are summarized in Table 3.

\section{HTP-induced head twitches:}

The head twitches were determined in mice using 5HTPinduced head twitches method. Mice were grouped and administered test compounds $(5 \mathrm{mg} / \mathrm{kg})$ and control similarly but the standard group received olanzapine $(1 \mathrm{mg} / \mathrm{kg})$. The head twitches in mice were counted after $20 \mathrm{~min}$ of $5 \mathrm{HTP}(100 \mathrm{mg} / \mathrm{kg})$ administration at an interval of $5 \mathrm{~min}$ and for a period of $1 \mathrm{~h}^{[18]}$. The results are summarized in Table 3.

\section{Acute oral toxicity study (up and down method, OECD guideline 425):}

The $\mathrm{LD}_{50}$ was calculated using the method of maximum likelihood. This test consists of a single ordered dose progression in which animals are dosed, one at a time, at a minimum of 48-h intervals. The first animal receives a dose a step below the level of the best estimate of the $\mathrm{LD}_{50}$. If the animal survives, the dose for the next animal is increased by (a factor of) 3.2 times of the original dose; if it dies, the dose for the next animal is decreased by a similar dose progression (note: 3.2 is the default factor corresponding to a dose progression of one half $\log$ unit). Each animal should be observed carefully for up to $48 \mathrm{~h}$ before making a decision on whether and how much to dose the next animal. That decision is based on the $48 \mathrm{~h}$ survival pattern of all the animals up to that time. The testing will be completed with only 4 animals after initial reversal in animal outcome ${ }^{[19,20]}$. The results are summarized in Table 3.

\section{Effective dose $\left(E D_{50}\right)$ determination:}

$\mathrm{ED}_{50}$ of all selected compounds was calculated by using probit log scale method of statistical analysis ${ }^{[21]}$. The $\mathrm{ED}_{50}$ was determined by using 5HTP-induced head twitches activity. Overnight fasted rats were used and each dose group consisted of 10 rats. After administration of the drugs, animals were observed for $2 \mathrm{~h}$ for maximum activity in particular group. The calculation was made by using Miller and Tainter method of statistical analysis ${ }^{[22]}$. Probit values were plotted against log doses and $\mathrm{ED}_{50}$ value as the dose that corresponds to porbit 5 . The results are summarized in Table 3.

\section{RESULTS AND DISCUSSION}

The results of all synthesized compounds with respect to physicochemical data, spectral analysis were summarized as follows, 7-hydroxy-4 methyl-2Hchromen-2-one (1), yield: $51 \%$, melting point (mp): $181^{\circ}$ TLC (benzene:ethyl acetate, 4:1, $\left.\mathrm{R}_{\mathrm{f}} 0.45\right)$ FTIR $\left(\mathrm{KBr}, \mathrm{Vmax}\right.$ in $\left.\mathrm{cm}^{-1}\right)$ : 3500 (O-H str), 3057 (Ar-C-H str), $1680(\mathrm{C}=\mathrm{O}, \mathrm{str}), 1601,1566$ and $1452(\mathrm{Ar}-\mathrm{C}=\mathrm{C}$,

TABLE 3: PHARMACOLOGICAL EVALUATION OF THE SYNTHESIZED COMPOUNDS

\begin{tabular}{|c|c|c|c|c|c|}
\hline \multirow{2}{*}{ Compounds } & \multicolumn{2}{|c|}{ \% Inhibition } & \multicolumn{2}{|c|}{ Selected potent compounds } & \multirow{2}{*}{$\begin{array}{c}\text { Final selection } \\
\text { Therapeutic index (TI) }\end{array}$} \\
\hline & Climbing $^{\mathrm{a}}$ & Head twitches $^{b}$ & Acute toxicityc $\left(\operatorname{LD}_{50}\right)$ & Effective dose $^{\mathrm{d}}\left(\mathrm{ED}_{50}\right)$ & \\
\hline Stde & 85 & 85 & - & - & - \\
\hline $4 a d$ & 65 & 36 & - & - & - \\
\hline $4 b$ & 60 & 72 & 1200 & 94 & 12.73 \\
\hline $4 c$ & 65 & 62 & 1700 & 159.9 & 10.63 \\
\hline $4 d$ & 70 & 57 & - & - & - \\
\hline $4 e$ & 80 & 77 & 797 & 54.7 & 14.57 \\
\hline $4 f$ & 78 & 45 & - & - & - \\
\hline $4 g$ & 63 & 55 & 2400 & 257 & 9.34 \\
\hline $4 \mathrm{~h}$ & 65 & 57 & - & - & - \\
\hline $4 i$ & 64 & 52 & 2100 & 198.2 & 10.60 \\
\hline $4 j$ & 62 & 60 & - & - & - \\
\hline $4 k$ & 72 & 68 & 1000 & 79 & 12.66 \\
\hline
\end{tabular}

aApomorphine-induced climbing behaviour in mice, ${ }^{*} n=6, p<0.05$, apomorphine $1 \mathrm{mg} / \mathrm{kg}$, '5HTP-induced head twitches in mice, ${ }^{*} \mathrm{n}=6$, $\mathrm{p}<0.05$, cacute toxicity studies by OECD guidelines using up and down method on rats, deffective dose determination by probit log scale

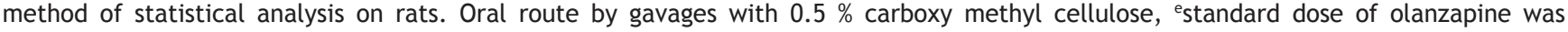
$1 \mathrm{mg} / \mathrm{kg}$, ip route with $0.5 \%$ carboxy methyl cellulose 
str), 1336 and 1159 (-C-CO-O, str), 1215(-C-O phenol), 746 (C-H out of plane) ${ }^{1} \mathrm{H}$ NMR (DMSO-d $\left., \delta, p p m\right)$ : 10.5 (bs, $1 \mathrm{H},-\mathrm{OH}), 7.51-7.53\left(\mathrm{~d}, 1 \mathrm{H}, \mathrm{C}_{5}-\mathrm{H}\right), 6.6-6.9$ $\left(\mathrm{m}, 2 \mathrm{H}, \mathrm{C}_{6}-\mathrm{H}\right), 6.06\left(\mathrm{~s}, 1 \mathrm{H}, \mathrm{C}_{3}-\mathrm{H}\right), 2.29\left(\mathrm{~s}, 3 \mathrm{H}, \mathrm{C}_{4}-\mathrm{CH}_{3}\right)$.

7-(2-Chloroethoxy)-4-methyl-2H-chromen-2-one (2), yield: $59 \%$, mp: $120-121^{\circ}$, TLC (benzene:ethylacetate, 4:1, $\mathrm{R}_{\mathrm{f}}$ 0.65) FTIR ( $\mathrm{KBr}$ Vmax in $\mathrm{cm}^{-1}$ ): 2931.6 (Ar-C-H str) 1724 (C=O str), 1682 (Ar-C $=\mathrm{C}$ str), 13861201 (-C-CO-O, str), 1240 (-C-O phenol), 644 (C-Cl str) and $746\left(\mathrm{C}-\mathrm{H}\right.$ out of plane) ${ }^{1} \mathrm{H}$ NMR (DMSO-d ${ }_{6}, \delta$, ppm): $7.51\left(\mathrm{~d}, 1 \mathrm{H}, \mathrm{C}_{5}-\mathrm{H}\right), 6.6-6.9\left(\mathrm{~m}, 2 \mathrm{H}, \mathrm{C}_{6}-\mathrm{H}\right.$ and $\mathrm{C}_{8}-$ $\mathrm{H}), 6\left(\mathrm{~s}, 1 \mathrm{H}, \mathrm{C}_{3}-\mathrm{H}\right), 2.15\left(\mathrm{~s}, 3 \mathrm{H}, \mathrm{C}_{4}-\mathrm{CH}_{3}\right) .4 .20(\mathrm{t}, 2 \mathrm{H}$, $\mathrm{O}-\mathrm{CH}_{2}$ linkage), 4.12 (t, 2H, $\mathrm{Cl}-\mathrm{CH}_{2}$ linkage).

7-(2-(benzo[d]thiazol-2-ylamino) ethoxy)-4-methyl$2 \mathrm{H}$-chromen-2-one derivatives (4a-4k), 7-(2-(benzo[d] thiazol-2-ylamino)ethoxy)-4-methyl-2H-chromen-2one (4a), FTIR (KBr Vmax in $\left.\mathrm{cm}^{-1}\right)$ : 3359.5 (N-H str), 2990 (Ar-C-H str), 1688 (C=O str), 1587-1440 (C=C str), 1248 (C-N str), 748 (C-S str) ${ }^{1} \mathrm{H}$ NMR (DMSO-d ${ }_{6}$, $\delta$, ppm): $8.6(\mathrm{t}, 1 \mathrm{H}, \mathrm{N}-\mathrm{H}), 7.16\left(\mathrm{~d}, 1 \mathrm{H}, \mathrm{C}_{5}-\mathrm{H}\right.$ in chromen2-one), 6.6-6.9 (d, 2H, $\mathrm{C}_{6}-\mathrm{H}$ and $\mathrm{C}_{8}-\mathrm{H}$ in chormen2-one), $5.90\left(\mathrm{~s}, 1 \mathrm{H}, \mathrm{C}_{3}-\mathrm{H}\right.$ in chromen-2-one), 2.3 (s, $3 \mathrm{H}, \mathrm{C}_{4}-\mathrm{CH}_{3}$ in chromen-2-one), 4.24 (t, $2 \mathrm{H}, \mathrm{O}-\mathrm{CH}_{2}$ linkage), 4.12 (t, 2H, N-CH linkage), $7.47(\mathrm{~m}, 2 \mathrm{H}$, $\mathrm{C}_{5},-\mathrm{H}$, and $\mathrm{C}_{6},-\mathrm{H}$ in benzothiazole $), 8.10\left(\mathrm{~d}, 2 \mathrm{H}, \mathrm{C}_{4},-\mathrm{H}\right.$ and $\mathrm{C}_{7}, \mathrm{H}$ in benzothiazole).

7-(2-(6-Chlorobenzo[d]thiazol-2-ylamino)ethoxy)-4methyl-2H-chromen-2-one (4b), FTIR ( $\mathrm{KBr} \mathrm{Vmax}$ in $\mathrm{cm}^{-1}$ ): 3211 (N-H str), 2966 (C-H str), 1732 (C=O str), 1458-1365 (C=C str), 1277 (C-N str), 1171 (-CO-O-C str), 781 (C-S str) ${ }^{1} \mathrm{H}$ NMR (DMSO-d $\left.{ }_{6}, \delta, \mathrm{ppm}\right): 9.11$ $(\mathrm{t}, 1 \mathrm{H}, \mathrm{N}-\mathrm{H}), 7.23\left(\mathrm{~d}, 1 \mathrm{H}, \mathrm{C}_{5}-\mathrm{H}\right.$ in chromen-2-one), 6.6-6.9 (d, 2H, $\mathrm{C}_{6}-\mathrm{H}$ and $\mathrm{C}_{8}-\mathrm{H}$ in chormen-2-one), 6.05 (s, $1 \mathrm{H}, \mathrm{C}_{3}-\mathrm{H}$ in chromen-2-one), $2.0\left(\mathrm{~s}, 3 \mathrm{H}, \mathrm{C}_{4}-\mathrm{CH}_{3}\right.$ in chromen-2-one). 4.5 (t, 2H, O- $\mathrm{CH}_{2}$ linkage), 4.60 (t, 2H, $\mathrm{NH}-\mathrm{CH}_{2}$ linkage), $7.60\left(\mathrm{~d}, 1 \mathrm{H}, \mathrm{C}_{5},-\mathrm{H}\right.$ in benzothiazole), $8.15\left(\mathrm{~d}, 2 \mathrm{H}, \mathrm{C}_{4},-\mathrm{H}\right.$ and $\mathrm{C}_{7}, \mathrm{H}$ in benzothiazole).

7-(2-(6-methoxybenzo[d]thiazol-2-ylamino)ethoxy)4-methyl-2H-chromen-2-one (4c), FTIR ( $\mathrm{KBr}$ Vmax in $\left.\mathrm{cm}^{-1}\right): 3410(\mathrm{~N}-\mathrm{H}$ str), 2854 (C-H str), $1715(\mathrm{C}=\mathrm{O}$ str), 1452 (C=C str), 1264 (C-N str), 1134 (-CO-O-C str), 747 (C-S ben) ${ }^{1} \mathrm{H}$ NMR (DMSO-d $\left.\mathrm{d}_{6}, \delta, \mathrm{ppm}\right): 8.1$ $(\mathrm{t}, 1 \mathrm{H}, \mathrm{N}-\mathrm{H}), 7.4\left(\mathrm{~d}, 1 \mathrm{H}, \mathrm{C}_{5}-\mathrm{H}\right.$ in chromen-2-one), 6.5-6.9 (d, 2H, $\mathrm{C}_{6}-\mathrm{H}$ and $\mathrm{C}_{8}-\mathrm{H}$ in chormen-2-one), 5.6 $\left(\mathrm{s}, 1 \mathrm{H}, \mathrm{C}_{3}-\mathrm{H}\right.$ in chromen-2-one), $2.1\left(\mathrm{~s}, 3 \mathrm{H}, \mathrm{C}_{4}-\mathrm{CH}_{3}\right.$ in chromen-2-one), $4.12\left(\mathrm{t}, 2 \mathrm{H}, \mathrm{O}-\mathrm{CH}_{2}\right.$ linkage), 4.0 $\left(\mathrm{t}, 2 \mathrm{H}, \mathrm{N}-\mathrm{CH}_{2}\right.$ linkage), $7.6\left(\mathrm{~s}, 1 \mathrm{H}, \mathrm{C}_{7},-\mathrm{H}\right.$ in benzothiazole), 8.1 (d, $1 \mathrm{H}, \mathrm{C}_{4}, \mathrm{H}$ in benzothiazole), 7.1 $\left(\mathrm{d}, 1 \mathrm{H}, \mathrm{C}_{5},-\mathrm{H}\right.$ in benzothiazole $), 3.7\left(\mathrm{~s}, 3 \mathrm{H}, \mathrm{OCH}_{3}\right.$ in benzothiazole).

7-(2-(6-nitrobenzo[d]thiazol-2-ylamino)ethoxy)-4methyl-2H-chromen-2-one (4d), FTIR (KBr Vmax in $\left.\mathrm{cm}^{-1}\right): 3341(\mathrm{~N}-\mathrm{H}$ str $), 1685(\mathrm{C}=\mathrm{O}$ str $), 1588(\mathrm{C}=\mathrm{C}$ str), 1310 (C-O-O str), 1266 (C-N str), 754 (C-N ben) ${ }^{1} \mathrm{H}$ NMR (DMSO-d $\left.{ }_{6}, \delta, p p m\right): 8.5(\mathrm{t}, 1 \mathrm{H}, \mathrm{N}-\mathrm{H}), 7.5$ (d, $1 \mathrm{H}, \mathrm{C}_{5}$-H in chromen-2-one), 6.5-6.9 (d, 2H, $\mathrm{C}_{6}$-Hand $\mathrm{C}_{8}-\mathrm{H}$ in chormen-2-one), $6.2\left(\mathrm{~s}, 1 \mathrm{H}, \mathrm{C}_{3}-\mathrm{H}\right.$ in chromen2-one), 2.1 (s, 3H, $\mathrm{C}_{4}-\mathrm{CH}_{3}$ in chromen-2-one). 4.0 (t, 2H, O- $\mathrm{CH}_{2}$ linkage), 4.2 ( $\mathrm{t}, 2 \mathrm{H}, \mathrm{N}-\mathrm{CH}_{2}$ linkage), $8.47\left(\mathrm{~m}, 2 \mathrm{H}, \mathrm{C}_{4},-\mathrm{H}\right.$ and $\mathrm{C}_{5},-\mathrm{H}$ in benzothiazole), 8.56 ( $\mathrm{s}, 1 \mathrm{H}, \mathrm{C}_{7},-\mathrm{H}$ in benzothiazole).

7-(2-(4-chlorobenzo[d]thiazol-2-ylamino)ethoxy)-4methyl-2H-chromen-2-one (4e), FTIR (KBr Vmax in $\left.\mathrm{cm}^{-1}\right): 3310(\mathrm{~N}-\mathrm{H}$ str), $2920(\mathrm{C}-\mathrm{H} \mathrm{str}), 1734(\mathrm{C}=\mathrm{O}$ str), 1504 ( $\mathrm{C}=\mathrm{C}$ str), 1140 (C-O str), 582 (C-Cl ben), 781 (C-S ben) ${ }^{1} \mathrm{H}$ NMR (DMSO-d $\mathrm{d}_{6} \delta, \mathrm{ppm}$ ): 9.1 $(\mathrm{t}, 1 \mathrm{H}, \mathrm{N}-\mathrm{H}), 7.20\left(\mathrm{~d}, 1 \mathrm{H}, \mathrm{C}_{5}-\mathrm{H}\right.$ in chromen-2-one), 6.5-6.9 (d, 2H, $\mathrm{C}_{6}-\mathrm{H}$ and $\mathrm{C}_{8}-\mathrm{H}$ in chormen-2-one), 6.1 (s, $1 \mathrm{H}, \mathrm{C}_{3}-\mathrm{H}$ in chromen-2-one), $2.4\left(\mathrm{~s}, 3 \mathrm{H}, \mathrm{C}_{4}-\mathrm{CH}_{3}\right.$ in chromen-2-one). $4.2\left(\mathrm{t}, 2 \mathrm{H}, \mathrm{O}-\mathrm{CH}_{2}\right.$ linkage $), 4.62$ (t, 2H, N-CH linkage), 7.4-7.6 ( $\mathrm{m}, 2 \mathrm{H}, \mathrm{C}_{5},-\mathrm{H}$ and $\mathrm{C}_{6},-\mathrm{H}$ in benzothiazole), 8.1 (d, $1 \mathrm{H}, \mathrm{C}_{7}, \mathrm{H}$ in benzothiazole).

7-(2-(6-fluorobenzo[d]thiazol-2-ylamino)ethoxy)-4methyl-2H-chromen-2-one (4f), FTIR ( $\mathrm{KBr} V \max$ in $\left.\mathrm{cm}^{-1}\right)$ : 3327 (N-H str), 2922 (C-H str), $1703(\mathrm{C}=\mathrm{O}$ str), 1596-1334 (C=C str), 1135 (C-O str), 929 (C-F ben), 751 (C-S ben) ${ }^{1} \mathrm{H}$ NMR (DMSO-d $\left.6, \delta, p p m\right): 9.3$ $(\mathrm{t}, 1 \mathrm{H}, \mathrm{N}-\mathrm{H}), 7.2\left(\mathrm{~d}, 1 \mathrm{H}, \mathrm{C}_{5}-\mathrm{H}\right.$ in chromen-2-one), 6.4$6.9\left(\mathrm{~d}, 2 \mathrm{H}, \mathrm{C}_{6}-\mathrm{H}\right.$ and $\mathrm{C}_{8}-\mathrm{H}$ in chormen-2-one), 6.20 (s, 1H, $\mathrm{C}_{3}-\mathrm{H}$ in chromen-2-one), $2.32\left(\mathrm{~s}, 3 \mathrm{H}, \mathrm{C}_{4}-\mathrm{CH}_{3}\right.$ in chromen-2-one). 4.11 (t, 2H, O- $\mathrm{CH}_{2}$ linkage), 4.32 (t, 2H, N-CH linkage), 7.2-7.8 (m, $2 \mathrm{H}, \mathrm{C}_{5},-\mathrm{H}$ and $\mathrm{C}_{7},-\mathrm{H}$ in benzothiazole), 8.01 (d, 2H, $\mathrm{C}_{4},-\mathrm{H}$ in benzothiazole).

7-(2-(5-chloro-6-fluorobenzo[d]thiazol-2-ylamino) ethoxy)-4-methyl-2H-chromen-2-one (4g), FTIR (KBr Vmax in $\mathrm{cm}^{-1}$ ): 3360 (N-H str), 2920 (C-H str), 1720 $(\mathrm{C}=\mathrm{O}$ str), 1589-1365 ( $\mathrm{C}=\mathrm{C}$ str), 667 ( $\mathrm{C}-\mathrm{Cl}$ ben $), 931$ (C-F ben), 1153 (CO-O-C str), 1253.9 (C-O-O str) ${ }^{1} \mathrm{H}$ NMR (DMSO-d $\left.{ }_{6}, \delta, p p m\right): 9.6(t, 1 \mathrm{H}, \mathrm{N}-\mathrm{H}), 7.26(\mathrm{~d}$, $1 \mathrm{H}, \mathrm{C}_{5}-\mathrm{H}$ in chromen-2-one), 6.5-6.9 (d, 2H, $\mathrm{C}_{6}-\mathrm{H}$ and $\mathrm{C}_{8}-\mathrm{H}$ in chormen-2-one), $6.13\left(\mathrm{~s}, 1 \mathrm{H}, \mathrm{C}_{3}-\mathrm{H}\right.$ in chromen-2-one), $2.17\left(\mathrm{~s}, 3 \mathrm{H}, \mathrm{C}_{4}-\mathrm{CH}_{3}\right.$ in chromen-2one), 4.34 (t, 2H, O- $\mathrm{CH}_{2}$ linkage), 4.48 (t, 2H, N-CH linkage), $7.89\left(\mathrm{~s}, 1 \mathrm{H}, \mathrm{C}_{7},-\mathrm{H}\right.$ in benzothiazole $), 8.30$ (s, 1H, $\mathrm{C}_{4},-\mathrm{H}$ in benzothiazole).

7-(2-(4-methylbenzo[d] thiazol-2-ylamino)ethoxy)4-methyl-2H-chromen-2-one (4h), FTIR (KBr Vmax 
in $\left.\mathrm{cm}^{-1}\right): 3342(\mathrm{~N}-\mathrm{H}$ str), $2920(\mathrm{C}-\mathrm{H}$ str), $1693(\mathrm{C}=\mathrm{O}$ str), 1565 (C=C str), 1259 (C-N str), 841 (C-H out of plane), 1174 (CO-O-C str), 743 (C-S Str) ${ }^{1} \mathrm{H}$ NMR (DMSO-d ${ }_{6}, \delta$, ppm): $8.3(\mathrm{t}, 1 \mathrm{H}, \mathrm{N}-\mathrm{H}), 7.10\left(\mathrm{~d}, 1 \mathrm{H}, \mathrm{C}_{5}-\mathrm{H}\right.$ in chromen-2-one), 6.6-6.9 (d, 2H, $\mathrm{C}_{6}-\mathrm{H}$ and $\mathrm{C}_{8}-\mathrm{H}$ in chormen-2-one), 5.90 (s, $1 \mathrm{H}, \mathrm{C}_{3}-\mathrm{H}$ in chromen-2-one), $1.9\left(\mathrm{~s}, 3 \mathrm{H}, \mathrm{C}_{4}-\mathrm{CH}_{3}\right.$ in chromen-2-one) $4.3\left(\mathrm{t}, 2 \mathrm{H}, \mathrm{O}-\mathrm{CH}_{2}\right.$ linkage), 4.10 (t, 2H, N-CH linkage), 7.3-7.4 (m, 2H, $\mathrm{C}_{5},-\mathrm{H}$ and $\mathrm{C}_{6},-\mathrm{H}$ in benzothiazole $), 8.0\left(\mathrm{~d}, 1 \mathrm{H}, \mathrm{C}_{7},-\mathrm{H}\right.$ in benzothiazole), 2.35 (s, $3 \mathrm{H},-\mathrm{CH}_{3}$ of benzothiazole).

7-(2-(6-methylbenzo[d]thiazol-2-ylamino)ethoxy)-4methyl-2H-chromen-2-one (4i), FTIR ( $\mathrm{KBr}$ Vmax in $\left.\mathrm{cm}^{-1}\right)$ : 3095 (N-H str), 2991 (C-H str), 1611 (C=O str), 1428 (C=C str), 1282 (C-N str), 1184 (CO-O-C str), 851 (C-H str), 732 (C-S str) ${ }^{1} \mathrm{H}$ NMR (DMSO-d $\left.{ }_{6}, \delta, p p m\right)$ : 8.1 (t, 1H, N-H), 6.96 (d, 1H, $\mathrm{C}_{5}-\mathrm{H}$ in chromen-2-one), 6.5-6.6 (d, 2H, $\mathrm{C}_{6}-\mathrm{H}$ and $\mathrm{C}_{8}-\mathrm{H}$ in chormen-2-one), 6.0 (s, 1H, $\mathrm{C}_{3}-\mathrm{H}$ in chromen-2-one), $2.23\left(\mathrm{~s}, 3 \mathrm{H}, \mathrm{C}_{4}-\mathrm{CH}_{3}\right.$ in chromen-2-one). 4.34 (t, 2H, O- $\mathrm{CH}_{2}$ linkage), 4.17 (t, 2H, N-CH linkage), 7.9-8.1 ( $\mathrm{m}, 2 \mathrm{H}, \mathrm{C}_{4}, \mathrm{H}$ and $\mathrm{C}_{7}, \mathrm{H}$ in benzothiazole), $7.4\left(\mathrm{~d}, 1 \mathrm{H}, \mathrm{C}_{5}, \mathrm{H}\right.$ in benzothiazole).

7-(2-(5-chlorobenzo[ $d]$ thiazol-2-ylamino)ethoxy)-4methyl-2H-chromen-2-one (4j), FTIR (KBr Vmax in $\mathrm{cm}^{-1}$ ): 3089 (N-H str), 2972 (C-H str), 1708 (C=O str), 1555 (C=C str), 1246 (C-N str), 1180 (CO-O-C str), 816 (C-H str) ${ }^{1} \mathrm{H}$ NMR (DMSO-d $\left.{ }_{6}, \delta, \mathrm{ppm}\right): 8.6$ (t, $1 \mathrm{H}$, $\mathrm{N}-\mathrm{H}), 7.16\left(\mathrm{~d}, 1 \mathrm{H}, \mathrm{C}_{5}-\mathrm{H}\right.$ in chromen-2-one), 6.6-6.9 $\left(\mathrm{d}, 2 \mathrm{H}, \mathrm{C}_{6}-\mathrm{H}\right.$ and $\mathrm{C}_{8}-\mathrm{H}$ in chormen-2-one), $5.90(\mathrm{~s}, 1 \mathrm{H}$, $\mathrm{C}_{3}$-H in chromen-2-one), 2.3 ( $\mathrm{s}, 3 \mathrm{H}, \mathrm{C}_{4}-\mathrm{CH}_{3}$ in chromen2-one), 4.24 (t, 2H, O-CH linkage), 4.12 (t, 2H, N-CH linkage), $7.56\left(\mathrm{~m}, 1 \mathrm{H}, \mathrm{C}_{6}, \mathrm{H}\right.$ in benzothiazole), 8-8.2 (d, $2 \mathrm{H}, \mathrm{C}_{4},-\mathrm{H}$ and $\mathrm{C}_{7},-\mathrm{H}$ in benzothiazole).

7-(2-(4-bromobenzo[d]thiazol-2-ylamino)ethoxy)-4methyl-2H-chromen-2-one (4k), FTIR (KBr Vmax in $\left.\mathrm{cm}^{-1}\right)$ : 3267 (N-H str), 2891 (C-H str), 1732 (C=O str), 1492 (C=C str), 1226 (C-N str), 1056 (CO-O-C str), 701 (C-S str), 631 (C-Cl str) ${ }^{1} \mathrm{H}$ NMR (DMSO-d 6 , $\delta$, ppm): $8.4(\mathrm{t}, 1 \mathrm{H}, \mathrm{N}-\mathrm{H}), 7.20\left(\mathrm{~d}, 1 \mathrm{H}, \mathrm{C}_{5}-\mathrm{H}\right.$ in chromen2-one), 6.6-6.9 (d, 2H, $\mathrm{C}_{6}-\mathrm{H}$ and $\mathrm{C}_{8}-\mathrm{H}$ in chormen2-one), $6.10\left(\mathrm{~s}, 1 \mathrm{H}, \mathrm{C}_{3}-\mathrm{H}\right.$ in chromen-2-one), 2.1 (s, 3H, $\mathrm{C}_{4}-\mathrm{CH}_{3}$ in chromen-2-one). $4.11\left(\mathrm{t}, 2 \mathrm{H}, \mathrm{O}-\mathrm{CH}_{2}\right.$ linkage), 4.18 (t, 2H, N-CH linkage), $7.72(\mathrm{~m}, 1 \mathrm{H}$, $\mathrm{C}_{5},-\mathrm{H}$ in benzothiazole), 8.1-8.2 (d, $2 \mathrm{H}, \mathrm{C}_{4},-\mathrm{H}$ and $\mathrm{C}_{7},-\mathrm{H}$ in benzothiazole).

Literature search revealed that $\mathrm{D}_{2}$ receptor blocking activity was the basis of development of typical antipsychotic agents with more side effects initially, but are highly effective to control positive symptoms of psychoses. Currently, the pharmacological basis of screening antipsychotics has extended to serotonergic receptor activity for development of atypical agents with less side effects as well as ability to control negative symptoms of psychoses.

Present study revealed that the synthesized compounds in series $4 a-4 k$ had a variety of antipsychotic activity. Compound $4 \mathrm{a}$, which was not substituted with any group on benzothiazole ring gave very low $\%$ inhibition of 5HTP-induced head twitches and hence $4 \mathrm{a}$ was not selected for acute toxicity studies. Compounds $4 \mathrm{~b}$, $4 \mathrm{e}, 4 \mathrm{j}$, which were substituted with a strong electron withdrawing group $\mathrm{Cl}$, exhibited good activity. In compound $4 \mathrm{j}$, where $\mathrm{Cl}$ was $\mathrm{m}$-substituted, lowered the serotonergic and dopaminergic activity. Compounds $4 \mathrm{f}$ and $4 \mathrm{k}$ were substituted by $\mathrm{F}$ and $\mathrm{Br}$ groups, respectively and both the groups were highly electron withdrawing but bromo-substituted compound had demonstrated better serotonergic activity compared to fluoro-substituted compound and these were selected for toxicity studies. Compound $4 \mathrm{~g}$ was substituted with $\mathrm{Cl}$ and $\mathrm{F}$ but did not show better activity than monosubstituted $\mathrm{Cl}$ or $\mathrm{F}$ compound. Compound $4 \mathrm{~d}$ was substituted with electron withdrawing $\mathrm{NO}_{2}$ group, but did exhibit better serotonergic activity. Compound $4 \mathrm{c}$ was substituted with $\mathrm{OCH}_{3}$ group and compounds $4 \mathrm{~h}$ and $4 \mathrm{i}$ were substituted with $\mathrm{CH}_{3}$ group. Compared to $\mathrm{CH}_{3}$ substituted compounds, $\mathrm{OCH}_{3}$ group was more electron withdrawing and as expected results of preliminary activity and toxicity supported this assumption.

Present study suggested that all synthesized compounds provided a chemical class of compounds that showed significant $\mathrm{D}_{2}$ antagonist activity in a pharmacological model predictive of antipsychotic activity and also had significant antagonistic activity at 5-HT receptor, an index of hypothesized atypical antipsychotic profile.

The compounds, which were substituted with chloro, bromo at ortho position and nitro, methyl and chloro at meta position showed significant $D_{2}$ receptor antagonism and such compounds were selected for acute toxicity test. The compounds, which were substituted with chloro, bromo at ortho position and chloro, fluoro and methoxy at meta position showed significant 5HT receptor antagonistic activity and only such compounds were selected for acute toxicity testing. The selected compounds for toxicity studies were $4 \mathrm{~b}, 4 \mathrm{c}, 4 \mathrm{e}, 4 \mathrm{~g}, 4 \mathrm{i}$ and $4 \mathrm{k}$. The effective dose $\left(\mathrm{ED}_{50}\right)$ was calculated for only those compounds, which were selected for acute toxicity studies. The therapeutic index 
(TI) was determined using $\mathrm{LD}_{50}$ and $\mathrm{ED}_{50}$ values. From this data it was found that compounds (4b), (4e) and (4k) have maximum TI. From overall data it is possible to conclude that compounds, 7-(2-(6-chlorobenzo[d] thiazol-2-ylamino)ethoxy)-4-methyl-2H-chromen-2one (4b) and 7-(2-(4-chlorobenzo[ $d]$ thiazol-2-ylamino) ethoxy)-4-methyl-2H-chromen-2-one (4e) have better atypical antipsychotic profile. Detailed chronic toxicity study as well as ligand binding studies are required for characterization of the compounds for understanding molecular mechanism, to predict therapeutic utility.

\section{Acknowledgements:}

The authors gratefully acknowledged and thanks TVES's College of Pharmacy, Faizpur, for providing animal studies on albino mice for biological evaluation of the compounds. Also thanks are due towards University of Pune for providing 1H NMR spectroscopy data.

\section{Conflict of interest:}

Authors declared that there is no conflict of interest.

\section{REFERENCES}

1. Kaczor AA, Silva AG, Loza MI, Kolb P, Castro M, Poso A. Structure based virtual screening for dopamine $\mathrm{D}_{2}$ receptor ligand as potential antipsychotics. Chem Med Chem 2016;11(7):718-29.

2. Younkin J, Gaitonde SA, Ellaithy A, Vekariya R, Baki $\mathrm{L}$, Moreno JL, et al. Reformulation a pharmacophore for $5 \mathrm{HT}_{2 \mathrm{~A}}$ serotonin receptor antagonist. ACS Chem Neurosci 2016;7(9):1292-9.

3. Reeves S, Eggleston K, Cort E, McLachlan E, Brownings $\mathrm{S}$, Nair $\mathrm{A}$, et al. Therapeutic $\mathrm{D}_{2} / 3$ receptor occupancies and response with low amisulpride blood concentration in very late-onset schizophrenia-like psychosis. Int J Geriatr Psychiatry 2018;33(2):396-404.

4. Tauscher J, Hussain T, Agid O, Verhoeff NP, Wilson AA, Houle $\mathrm{S}$, et al. Equivalent occupancy of dopamine $\mathrm{D}_{1}$ and $\mathrm{D}_{2}$ receptors with clozapine: Differentiation from other atypical antipsychotics. Am J Psychiatry 2004;161(9):1620-5.

5. Seeman P. Dopamine $D_{2}$ receptors as treatment targets in schizophrenia. Clin Schizophr Relat Psychoses 2010;4(1):5673.

6. Murray R, Correll CU, Reynolds GP, Taylor D. Atypical antipsychotics: recent research findings and applications to clinical practice. Ther Adv Psychopharmacol 2017;7(1 Suppl):1-14.

7. Frederick CN, Marina M, Brain JL, Akira Sawa. Clozapine as a model for antipsychotic development. Neurotherapeutics 2017;14(3):750-61.

8. Choi YK, Gardner MP, Tarazi FI. Developmental effects of antipsychotic drugs on serotonin receptor subtypes. Synapse 2017;71(10):e21988.

9. Oerther S, Ahlenius S. Atypical antipsychotics and dopamine $\mathrm{D}_{1}$ receptor agonism: An in vivo experimental study using core temperature measurements in the rat. J Pharmacol Exp Ther 2000;292(2):731-6.

10. Christopher JS, John HK, Albert AC. MDL 100,907: A selective $5-\mathrm{HT}_{2 \mathrm{~A}}$ receptor antagonist for the treatment of schizophrenia. CNS Drug Rev 1997;3(1):49-67.

11. Kharadi DG, Shah AR, Ganguly B. Comparison of adverse effects of newer atypical antipsychotics: An evidence based review. J Young Pharm 2017;9(2):140-4.

12. Kapur S, Seeman P. Antipsychotic agents differ in how fast they come off the dopamine $\mathrm{D}_{2}$ receptors: Implications for atypical antipsychotic action. J Psychiatry Neurosci 2000;25(2):161-6.

13. Lin F, Li F, Wang C, Wang J, Yang Y, Yang L, et al. Mechanism exploration of arylpiperazine derivatives targeting the $5-\mathrm{HT}_{2 \mathrm{~A}}$ receptor by in silico methods. Molecule 2017;22(7):1064-86.

14. Kesten SR, Heffner TG, Johnson SJ, Pugsley TA, Wright JL, Wise LD. Design, synthesis, and evaluation of chromen-2ones as potent and selective human dopamine $\mathrm{D}_{4}$ antagonists. J Med Chem 1999;42(18):3718-25.

15. Pechmann HV, Cohen JB. Uber die Verbindungen der Phenole mit Acetessigather. Eur J Inorg Chem 1883;16:2119-28.

16. Sreenivasa GM, Jayachandran E, Shivakumar B, Jayaraj KK, Vijaykumar MM. Synthesis of bioactive molecule fluorobenzothiazole comprising potent heterocyclic moieties for anthelmentic activity. Arch Pharm Sci Res 2009;1(2):150-7.

17. Davis AS, Jenner P, Marsden CD. A comparison of motor behaviours in groups of rats distinguished by their climbing response to apomorphine. Br J Pharmacol 1986;87(1):129-37.

18. Chung IW, Moore NA, Oh WK, O'Neill MF, Ahn JS, Park $\mathrm{JB}$, et al. Behavioural pharmacology of polygalasaponins indicates potential antipsychotic efficacy. Pharmacol Biochem Behav 2002;71:191-5.

19. Bruce RD. An up and down procedure for acute toxicity testing. Fundam Appl Toxicol 1985;5(1):151-7.

20. Gad SC, Smith AC, Cramp AL, Gavigan FA, Derelanko MJ. Innovative Designs and practices for acute systemic toxicity studies. Drug Chem Toxicol 1984;7(5):423-34.

21. Kulkarni SK. Handbook of experimental pharmacology. 1st ed. Delhi, India: Vallabh Prakashan; 2002. p. 168-70.

22. Miller LC, Trainter ML. Estimation of the $\mathrm{ED}_{50}$ and its error by means of logarithmic-Probit graph paper. Proc Soc Exp Biol Med 1944;1:57-261. 